\author{
INTERNATIONAL JOURNAL OF \\ SUPPLY CHAIN, OPERATION \\ MANAGEMENT AND LOGISTICS \\ (IJSCOL) \\ WWW.ijscol.com
}

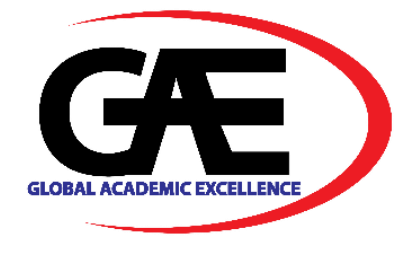

\title{
PERCEIVED SERVICE QUALITY, CUSTOMER SATISFACTION AND BEHAVIOURAL INTENTIONS TOWARDS HOSPITAL IN SABAH
}

\author{
Sidah Idris $^{1 *}$, Choong Fui Kiun ${ }^{2}$, Rini Suryati Sulong ${ }^{3}$, Oscar Dausin ${ }^{4}$
}

1 Faculty of Business, Economics and Accountancy, Universiti Malaysia Sabah, Kota Kinabalu, Sabah, Malaysia Email: syaidah@ums.edu.my

2 Faculty of Business, Economics and Accountancy, Universiti Malaysia Sabah, Kota Kinabalu, Sabah, Malaysia Email: choongcelyn89@gmail.com

3 Faculty of Business, Economics and Accountancy, Universiti Malaysia Sabah, Kota Kinabalu, Sabah, Malaysia Email: yati2002@ums.edu.my

4 Faculty of Business, Economics and Accountancy, Universiti Malaysia Sabah, Kota Kinabalu, Sabah, Malaysia Email: odousin@ums.edu.my

* Corresponding Author

\section{Article Info:}

\section{Article history:}

Received date: 03.11.2020

Revised date: 01.12.2020

Accepted date: 06.12.2020

Published date: 10.12 .2020

\section{To cite this document:}

Idris, S., Kiun, C. F., Sulong, R. S., Dousin, O. (2020). Perceived Service Quality, Customer Satisfaction and Behavioural Intentions Towards Hospital in Sabah. International Journal of Supply Chain, Operation Management and Logistics, 1 (2), 0120-35.

\section{DOI: $10.35631 /$ IJSCOL.12003}

This work is licensed under $\mathrm{CC}$ BY 4.0

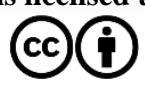

\begin{abstract}
:
The Health system in Malaysia including hospitals, clinics, and community health agencies can be very different from other operational work environments. Healthcare systems are complex and there are many things that need to know about types of hospital operation systems, patient care, insurance, healthcare providers, and legal issues. This study aimed at examining the relationship between perceived service quality, customer satisfaction, and behavioural intentions in the context of the hospital in Sabah, Malaysia. Information from 208 respondents was used through questionnaires for the purposed of statistical data analysis using SmartPLS. The result showed only tangibles and empathy supports behavioural intentions in relation to the retail pharmacy within Malaysia. This study tested relationships of tangibles, assurance, and empathy with customer satisfaction respectively were shown to be significantly positive as well. A positive relationship between customer satisfaction and behavioural intentions was also observed in this study. As for the mediation analysis, the outcome indicated that tangibles, assurance, and empathy respectively have an indirect relationship with behavioural intentions mediated by customer satisfaction. Additional findings also showed that, while the direct effects of empathy on behavioural intentions were significant, the indirect impact was noted to be greater for behavioural intentions in connection with customer satisfaction as mediation. The result also showed that relative to other perceived service quality, empathy has the most impact on customer satisfaction as well as behavioural intentions respectively. The findings from this study significant to this industry which contribute to policymakers, service providers, and other stakeholders.
\end{abstract}




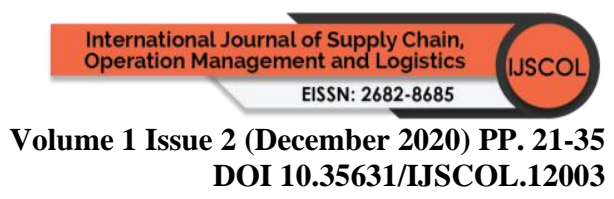

Keywords:

Operation Dimensions, Perceive Service Quality, Customer Satisfaction, Behavioural Intention, Healthcare Industry

\section{Introduction}

The Malaysian healthcare system is advanced due to extensive support from the Malaysian government through investment in hospital's medical infrastructure (PEMANDU, 2020). Healthcare operation systems are organized differently around the globe. The operation systems vary in the proportion of care delivered by public versus private facilities. The improvements in the last ten years are significant enough to be on par with well-developed countries, comprising of both well-trained medical staff and excellent hospital facilities. Public healthcare is the cheaper option; however private hospitals have their advantages over public ones. For instance, many public hospitals are overcrowded from higher number of patients. Private healthcare, on the other hand, has more doctors, due to higher working salaries within the private sphere. Another advantage is that private hospitals offer faster services for their patients since the ratio of doctors to patients is higher (The Borneo Post, 2010).

Health system operated in Malaysia is a two-tier framework where both public and private sectors coexist and complement each other in delivering healthcare that meet the different needs and demands of the vast population (Hassali, 2014). In the emerging clinical environment, the healthcare operations system will demand more clinical integration, more risk for providers, and more transparency for quality, outcomes, and cost. Various literatures were published in distinct context on the link between the quality of service, satisfaction and behavioural intentions. The findings were positive when improved quality of service resulted in increased satisfaction among customers (Ali, Faizan, Amin and Nasharuddin, 2013; Allameh et al, 2015; Biscaia et al, 2013; Riadh Ladhari, 2009). However, contradicting findings were also found indicating that satisfaction and perceived value have no critical effect on patient loyalty which would be reflected in behavioural intentions (Sumaedi et al, 2014). For example, the healthcare industry has not supported Cronin and Taylor (1994) customer satisfaction, being a moderation between service quality and behavioural intentions, despite having an impact in other industries like communication, transportation and recreation industry.

Despite various research into perceived service quality, satisfaction and behavioural intentions (Parasuraman et al., 1988; Boulding et al.,1993; Cronin and Taylor, 1992); limited studies have so far been explored in the area of healthcare in Malaysia. Subsequently, previous research not only provide necessary strategic recommendations to the operation of general or private hospital as a service provider to achieve the desired service quality goal and but also in improving behavioural intentions among customers. Newest study by Alumran et. al. (2020) showed in their study has implications for a potential positive impact on the improvement of the overall quality of health care services.

This has become the principal motivation for this study, which is to bridge the research disparity and subsequently, centre around the perceived service quality on hospitals in Sabah and how it would impact behavioural intentions. On top of that, as customer satisfaction was also shown to be an important factor in behavioural intentions (Zeithaml et al., 1996; Aagja and Garg, 2010; Oliver, 1980; Anthanassopoulos et al., 2001; Riadh Ladhari, 2009; Gaur et al., 2011). Therefore, this study aims to examine the role of perceived service quality towards Copyright (C) GLOBAL ACADEMIC EXCELLENCE (M) SDN BHD - All rights reserved 


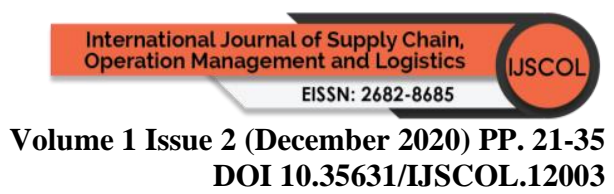

behavioural intentions as mediated by the effect of customer satisfaction among hospitals in Sabah.

\section{Literature Review}

\section{Tri-component Attitude Model}

Customer's future intentions and their decisions to repurchase a service and to indulge in positive word-of-mouth, depends often on a complete evaluation of service and supplier, based on the experience of multiple transactions of services with the given supplier (Caro and Gracia, 2007). This study tested the links between perceived service quality, customer satisfaction and behavioural intentions were explained using this model. The model is commonly used in consumer marketing research to examine the attitudes of consumers towards certain subject or objects. There are 3 components in the construct attitude of tricomponent model, namely cognitive component (Thinking/Knowledge), an affective component (feeling) and a conative component (behaviour) (Assael, 2004; Schiffman and Kanuk, 2004; Solomon, 2002). Quality of healthcare being provided within healthcare organizations may drive the organizations' success in terms of profitability and patient satisfaction.

Attitude is a learned process whereby it could be shaped by consumers perception and understanding on the subject matter, and this perception can be formed based on one's exposure, life experiences or personal situations when in contact with the related subject matter (Antonides and Van Raaij, 1998), thus, leading to differences in perception and view of the reality and in the context of this study, differences in perception and view on pharmacist roles and services (Antonides and Van Raaij, 1998). In summary, customer choice and behavioural intentions would be influenced by both cognitive (for instance, from personal experiences) and affective components (for example, from promotion) (Argawal and Malhotra, 2005; Lazarus, 1982).

As mentioned, negative behavioural intentions toward a firm or body could lead to negative outcomes like brand switching, negative word of mouth, or even complaints on their negative experiences to others (Caruana, 2002; Lewis, 1991; Newman, 2001). In Lazarus (1991), the cognition-leads-to-emotions approach explained the necessary cognition role to emotions, in which consumers were conscious of their cognition before their affects, thus resulting in behavioural intentions or actual behaviour (conation and actions). In this study, service quality is a representative of a cognitive judgement, whereas satisfaction is represented as an affective construct (Gooding, 1995; Oliver, 1993), and thus place service quality prior to satisfaction (Goldstein and Schweikhart, 2002; Oliver, 1993; Rust and Oliver, 1994). In addition, tangible evidence of services, for instance, interior design, furnishings, clothing, along with other dimensions (reliability, responsiveness, assurance and empathy), a mix of service marketing can be created to meet the needs of consumers and subsequently, customer satisfaction would be achieved as well (Darry 2015).

\section{Behavioural Intentions}

According to Ladhari (2009), a division into either a favourable or unfavourable signal in which customers would either remain with or leave the service provider relationship can be used to explain behavioural intentions. The favourable dimension of behavioural intentions can be referred to as the likelihood of positive endorsement of word-of-mouth, willingness to pay a high price and spend more; and loyalty (Ladhari, 2009; Zeithaml et al., 1996); while the 


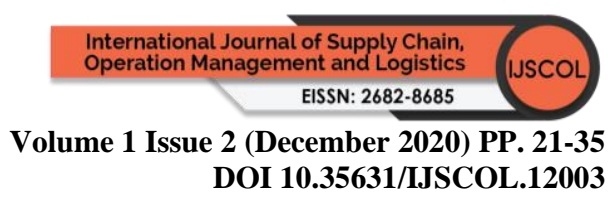

unfavourable dimensions of behavioural intentions can be related to the spread of negative words and experiences to others (Caruana, 2002; Lewis, 1991; Newman, 2001); spending less (Zeithaml et al., 1996); as well as having the intention of changing to competitors (Anthanassopoulos et al., 2001).

In this model, endorsement of word-of-mouth regardless of its positive or negative bias, is an informal communication that takes place between two or more consumers about a product or a service. For example, a pleased customer is more likely to introduce or recommend its products or services to their friends and family (Anderson, 1998; Ryu and Han, 2009; Finkelstein et al., 1999). This can also be further understood with the definition of recommendation based on Arndt (1968). Recommendations can be described as personal-toperson interaction, when there is willingness of a non-commercial communicator to engage with a current customer concerning a service provider who is deemed not to achieve financial profit from the interaction received in regards to a brand, product or service (Host and KnieAndersen, 2004; Arndt, 1968).

In addition, as for loyalty behaviour, it involves the relationship that has been built and maintained with the consumers by the service provider, where consumers would want to come back to the service establishment for its products and services (Zeithaml et al., 1996; Kessler and Mylod, 2011). In these studies, they believed consistent engagement by the consumers due to return for the desired product or services of their liking in the future (Oliver, 1997; Bei and Chiao, 2001). The perceptions of respondents may differ significantly in the other regions of the country due to differences in the number of public and private health facilities in these other region (Shan et al., 2016). Therefore, in the context of healthcare services in this study, the subject consumers' behavioural intentions are in reference to endorsement of word-ofmouth, willingness to pay more and loyalty towards preferred retail pharmacy for its health services and products.

\section{Perceived Service Quality}

Previous studies defined service quality as a consumers' judgement, impression and evaluation process, in which the consumer compares service expectations with service perceptions with regards to the overall excellence of the service providers (Grönroos, 1984; Cronin and Taylor, 1992; Boulding et al., 1993; Parasuraman, Zeithaml and Berry, 1985, 1988). The measurement of service quality has always been a controversial issue. The first instrument for measuring service quality was developed by Parasuraman et al. (1988) and Gronroos (1984). In healthcare services, its quality perception is in reference to the opinion of a patient/customer, which is reflected by the service provided that are most appropriate in yielding the best result reasonably expected by the patient/customer.

In healthcare, technical quality can be explained based on the technical accuracy relative to the conformity to professional specifications, whereas functional quality is in reference to the way in which the healthcare service is conveyed to the patients or customers. However, as majority public are unable to value the technical quality because of poor comprehension on the expertise, most in general will depend on functional attributes (for example: facilities, cleanliness, staff's attitudes, and others) as opposed to technical attributes while assessing service quality (Babakus and Boller, 1991; Gronroos, 2001). According to Duku, Nketiah-Amponsah and Pradhan (2018) in their study found that people's perceptions of healthcare quality may be shaped by their actual experiences at the health facilities, and these experiences differ depending on their insurance status. 


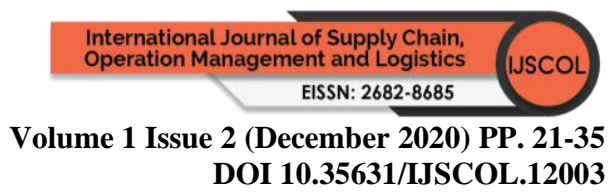

\section{Customer Satisfaction}

Customer satisfaction is an enjoyable fulfilment response towards a good, service, benefit or reward that is in reference to the judgement that a good, service, benefit or reward, provide an enjoyable level of consumption-related fulfilment, inclusive of levels of under- or overfulfilment (Oliver, 1997). Likewise, consumer satisfaction can be explained as a summary of either at a transaction-specific level or an overall level of cognitive and affective reactions regarding a service encounter (Rust and Oliver, 1994). Sarker, Md \& Uddin, Borhan (2017) have comparable results which supported assurance and empathy having significant relationship with customer satisfaction in Bangladesh's retail private commercial banking sector. Therefore, this study used overall satisfaction as a function to better understand consumers in the context of healthcare services as it has been affirmed to be more applicable for the apprehension of consumer responses.

\section{Perceived Service Quality, Customer Satisfaction, and Behavioural intentions}

Inconsistent opinions toward relation linking service quality with customer satisfaction were observed where there were differences in perspective from different studies. In one perspective, customer satisfaction is seen as an antecedent with a given service experience, influence a perceived service quality where satisfaction would affect the outcome of the perceived quality service over time (Bitner and Hubbert 1994; Mohr and Bitner 1995; Oliver, 1981; Parasuraman et al., 1988).

There were also other opposite views indicating that customer satisfaction as an emotive satisfaction construct, as a resultant of service quality as cognitive evaluation, in which desired perceived service quality would directly influence the improvement of satisfaction (Dabholkar et al., 1996; Brady and Robertson 2001; Cronin and Taylor 1992; Cronin et al., 2000; Gotlieb, Grewal, and Brown, 1994). Nevertheless, study by Dabholkar and Overby (2005) claimed that the assessment of quality of services comes before customer satisfaction for normal or nonextreme services in which the services provided are of acceptable range that enable customers to rationally and cognitively evaluate the services. The most significant predictor of patient satisfaction is shaped by perceived high quality of service delivery, empathic and caring interpersonal interaction (Shan et al, 2016). However, for extreme service assessments where expectations are greatly unfulfilled, an opposite relationship was observed where customer satisfaction precede service quality.

According to Ali and Amin (2014), a significant relationship between perceived quality, customer satisfaction and behavioural intentions was observed to be evident. Several conclusions have also been made about service quality and the satisfaction of customers with behavioural intentions, be it direct or indirect. Therefore, given that healthcare is an important concern for everyone, this study would like to examine whether the service quality would have a direct consequence towards behavioural intentions or indirect outcome with regards to customer satisfaction (Dagger et al, 2007; Parasuraman et al., 1991; Boulding et al.,1993; Cronin and Taylor, 1992).

\section{Methodology}

This study employed questionnaire in examining the relationships between perceived service quality (independent variable), overall customer satisfaction (mediator) and behavioural intentions (dependent variable). Figure 1 shown the research framework of this research. This study aims to identify the relationship between perceived service quality indicators as an 


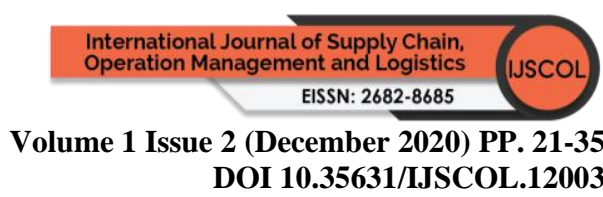

independent variable with behavioural intention as a dependant variable among patients or users of hospitals in Sabah and mediate by customer satisfaction.

This study focusing on Sabah hospitals as a subject because it is time to identify the indicators of providing good quality of services among hospitals in Sabah. In addition, during the Covid19 pandemic, healthcare industry especially in Sabah including workers and public healthcare facilities are urgently needed to improve. According to the Malaysian Medical Association (2020), in the serious situation the Sabah state needs all the help in terms of personal protective equipment, medical equipment, and financial aid for their healthcare needs as support by good quality of services.

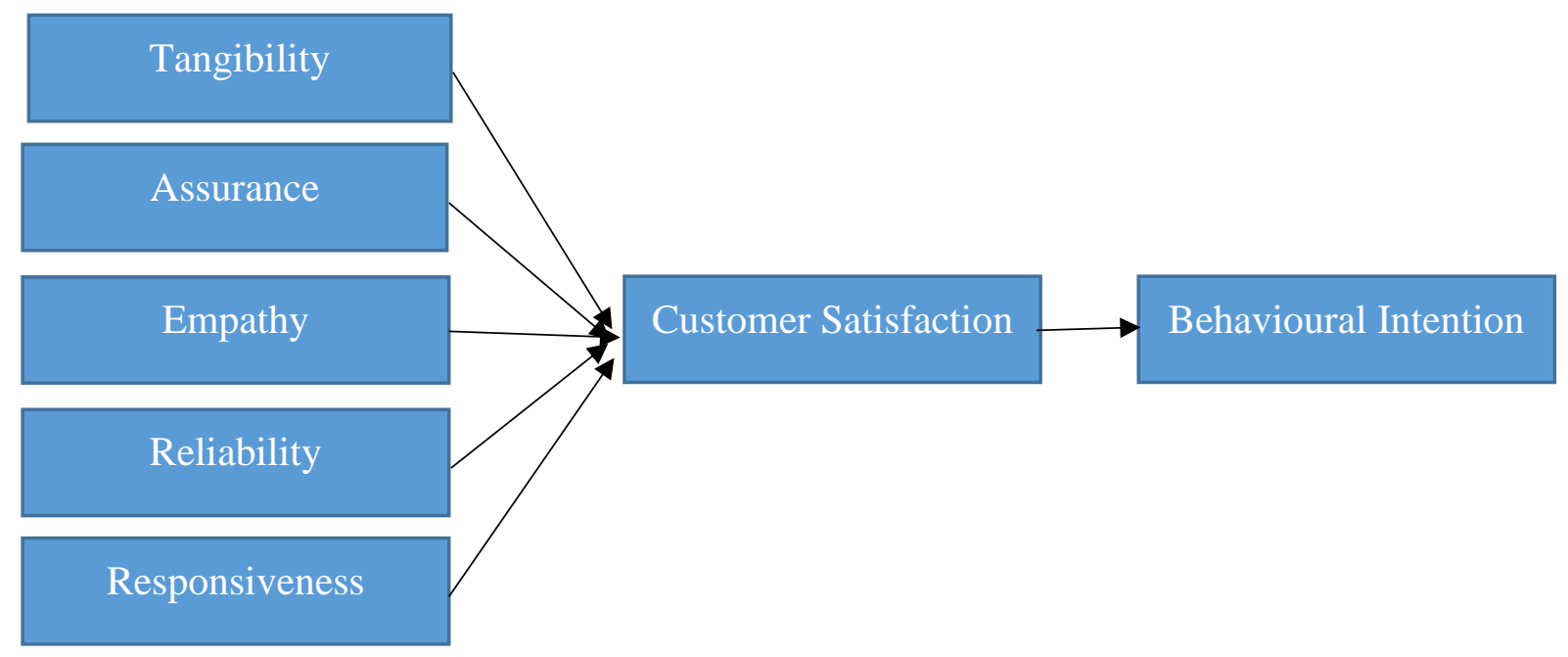

Figure 1: Research Framework

The self-administered survey is circulated to participants using the non-probability convenient sampling method. This study focuses on respondents who are at the age of 18 years and above and had visited a hospital of at least once previously for health-related matters which were asked by the questions in filtering question in the demographic profile. This is to make sure that the respondents enrolled in this investigation have adequate experience to assess the hospital services in general. Total of 213 sets of questionnaires from total 450 distributed questionnaire have been gathered for this study and 208 sets were used for data analysis after screening based on inclusion criteria of the study.

The questionnaire questions and statements are divided into few sections; Section A collects information on respondent's demography background; Section B measures respondents' patterns for visiting hospitals; Section $\mathrm{C}$ gathers information on the perceived service quality; Section D on customer satisfaction towards the service provided and lastly, section E measures the behavioural intentions. This study using a seven-point Likert scale, with the left end corresponds to (1) strongly disagree, and the right end corresponds to (7) strongly agree. The information gathered from the questionnaire dissected using partial least squares structural equation modelling (PLS-SEM), with the assistance of SmartPLS 3 and SPSS version 25. PLS-SEM is used in this study as it helps in the prediction of dependent variables, perceived service quality (Roldán and Sánchez-Franco, 2012), and customer satisfaction as mediator between perceived service quality and behavioural intentions (Hair et al., 2014; Nitzl et al., 2016; Richter et al., 2016). 
The study hypothesis:

$\mathrm{H} 1$ : There is a positive relationship between perceived service quality (PSQ) and behavioural intentions (BI)

$\mathrm{H} 2$ : There is a positive relationship between Customer Satisfaction (CS) and Behavioural intentions (BI).

H3: Customer satisfaction (CS) mediates the relationship between perceived service quality (PSQ) and behavioural intentions (BI)

\section{Data Analysis and Findings}

This study involved 208 number of respondents. Table 1 and 2 shows respondents' profile and the frequency and reason for visiting hospitals. The mean and standard deviation values for all the constructs were shown in table 3. These were obtained using SPSS version 23.

Table 1 Respondent's Profile

\begin{tabular}{llll}
\hline Profile & Description & Frequency & Percentage \\
\hline Gender & Male & 88 & 42.3 \\
& Female & 120 & 57.7 \\
\hline Age & $18-35$ & 125 & 60.1 \\
& $36-50$ & 46 & 22.1 \\
& $>50$ & 37 & 17.8 \\
\hline Marital Status & Single & 96 & 46.2 \\
& Married Single & 112 & 53.8 \\
\hline Occupation & Professional & 143 & 68.8 \\
& Non-Professional & 28 & 13.5 \\
& Manual Worker & 5 & 2.4 \\
& Housewife & 7 & 3.3 \\
& Student & 9 & 4.3 \\
& Unemployed & 7 & 0.5 \\
& Retiree & 15 & 7.7 \\
\hline Monthly Household & $1,000-1,999$ & 14 & 6.7 \\
Income (RM) & $2,000-2,999$ & 20 & 9.6 \\
& $3,000-3,999$ & 33 & 14.9 \\
& $4,000-4,999$ & 29 & 13.9 \\
& & & \\
& $\geq 5,000$ & 102 & 49.0 \\
\hline
\end{tabular}

Table 2 Frequency and Reason of Visiting Hospital

\section{Frequency of Visiting}

Once or more a week

Frequency Percentage

Two to three times a month

$63 \quad 30.3$

At least once every few months

$118 \quad 56.7$

Once a year

Very seldom

5

2.4

\section{Reason for Visiting}

Doctor review 
To prescription para-pharmaceuticals and non-prescription medications.

To purchase para-pharmaceutical products

To ask for doctor advice

To purchase monitoring devices, e.g., blood pressure

devices and blood glucose meters.

To get general health information.

To get first-aid information

Table 3 Descriptive Analysis for the Respondents

\begin{tabular}{lcc}
\hline \multicolumn{1}{c}{ Constructs } & Mean & SD \\
\hline Tangibles & 5.2392 & 1.09327 \\
Reliability & 5.5904 & 1.04521 \\
Responsiveness & 5.5288 & 1.04014 \\
Assurance & 5.7139 & 1.01642 \\
Satisfaction & 5.5397 & 0.9826 \\
Behavioural Intention & 4.9824 & 1.12656 \\
\hline
\end{tabular}

\section{Measurement Model}

Partial least squares structural equation modelling (PLS-SEM) is used in examining the hypotheses. Due to its robustness, it is commonly used for data analysis (Penga and Lai, 2012). PLS-SEM was used in this study because it helps in the prediction of dependent variables (Roldán and Sánchez-Franco, 2012), as well as the incremental character in this study that is having Customer Satisfaction mediating between training satisfaction and turnover intention (Hair et al., 2014; Nitzl et al., 2016; Richter et al., 2016). In the first segment, measurement model testing was performed (Figure 1) (i.e. internal consistency reliability, convergent and discriminant validity) using SmartPLS, version 3.2.8.

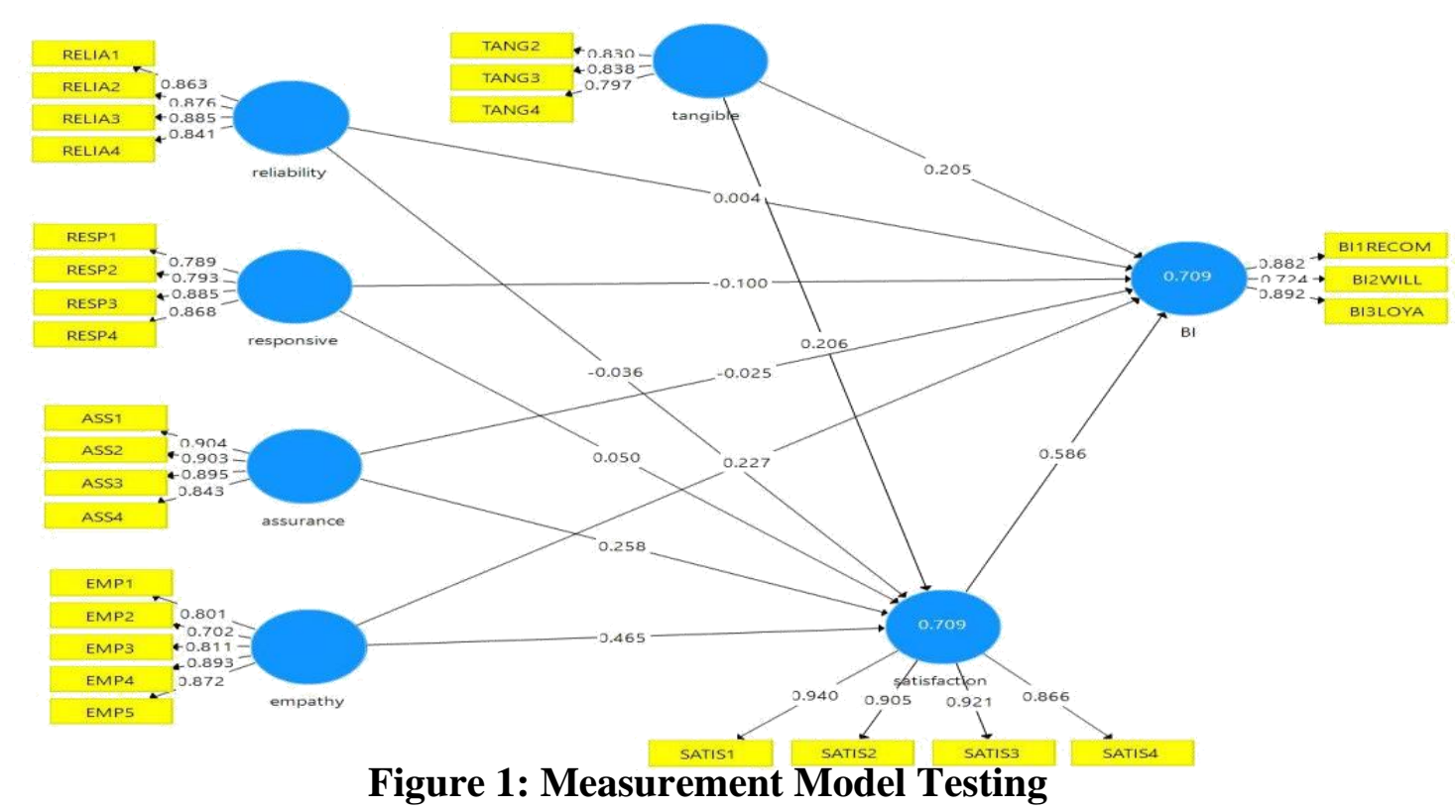


Table 4 listed out the Measurement Structure and Items as for convergent validity results.

Table 4 Convergent Validity

\begin{tabular}{|c|c|c|c|c|}
\hline Construct & Items & Loadings & $\begin{array}{l}\text { Composite } \\
\text { Reliability }\end{array}$ & AVE \\
\hline \multirow[t]{4}{*}{ Assurance } & ASS1 & 0.904 & \multirow{4}{*}{0.936} & \multirow{4}{*}{0.786} \\
\hline & ASS2 & 0.903 & & \\
\hline & ASS3 & 0.895 & & \\
\hline & ASS4 & 0.843 & & \\
\hline \multirow[t]{5}{*}{ Empathy } & EMP1 & 0.801 & \multirow{5}{*}{0.91} & \multirow{5}{*}{0.67} \\
\hline & EMP2 & 0.702 & & \\
\hline & EMP3 & 0.811 & & \\
\hline & EMP4 & 0.893 & & \\
\hline & EMP5 & 0.872 & & \\
\hline \multirow[t]{4}{*}{ Reliability } & RELIA 1 & 0.863 & \multirow{4}{*}{0.923} & \multirow{4}{*}{0.75} \\
\hline & RELIA 2 & 0.876 & & \\
\hline & RELIA 3 & 0.885 & & \\
\hline & RELIA 4 & 0.841 & & \\
\hline \multirow[t]{4}{*}{ Responsive } & RESPI 1 & 0.789 & \multirow{4}{*}{0.902} & \multirow{4}{*}{0.697} \\
\hline & RESPI 2 & 0.793 & & \\
\hline & RESPI 3 & 0.885 & & \\
\hline & RESPI 4 & 0.868 & & \\
\hline \multirow[t]{3}{*}{ Tangible } & TANG 2 & 0.83 & \multirow{3}{*}{0.862} & \multirow{3}{*}{0.675} \\
\hline & TANG 3 & 0.838 & & \\
\hline & TANG 4 & 0.797 & & \\
\hline \multirow[t]{4}{*}{ Satisfaction } & SATIS 1 & 0.94 & \multirow{4}{*}{0.95} & \multirow{4}{*}{0.825} \\
\hline & SATIS 2 & 0.905 & & \\
\hline & SATIS 3 & 0.921 & & \\
\hline & SATIS 4 & 0.866 & & \\
\hline \multirow{3}{*}{$\begin{array}{c}\text { Behavioural } \\
\text { Intention }\end{array}$} & BI1RECOM & 0.882 & \multirow{3}{*}{0.874} & \multirow{3}{*}{0.699} \\
\hline & B12WILL & 0.724 & & \\
\hline & BI3LOYA & 0.892 & & \\
\hline
\end{tabular}

\section{Structural Measurement}

In the second segment, the structural model was examined (Figure 2) to test direct and indirect relationship. The result from this segment will answer the hypotheses tested in this study. This model examines the causal links among constructs (Sang et al., 2010). In order to assess the statistical significance of the suggested model, bootstrapping method with 5,000 re-sampling was used (Hair et al. 2017). 


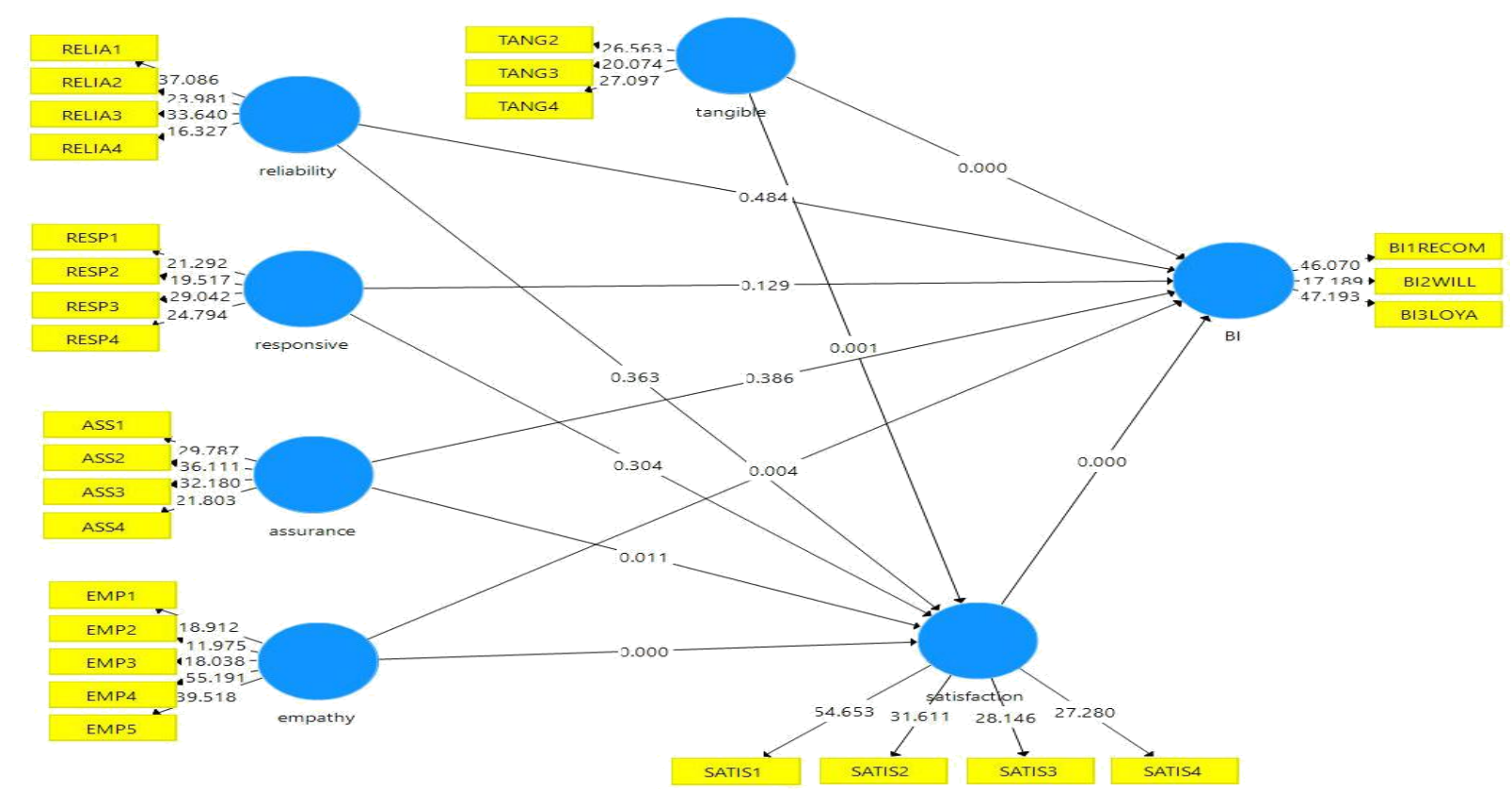

Figure 2: Structural Model Testing

\section{Coefficient of Determination $\left(R^{2}\right)$}

The $\mathrm{R}^{2}$ value indicates the amount of variance in a dependent variable is explained by the independent variables. Substantial, moderate and weak values of $\mathrm{R}^{2}$ are in reference of 0,75 , 0,50 and 0,25 (Hair et al., 2017). The greater the $\mathrm{R}^{2}$ value, the better the structural model can be predicted. As for this research, the $\mathrm{R}^{2}$ values are therefore 0.709 respectively for behavioural intentions and customer satisfaction.

\section{Hypothesis Testing}

Path coefficients were performed to determine the significance of relationships among the variables in reference to the proposed hypotheses. T-value for all the independent and dependent variables were created using Smart PLS 3 bootstrapping, in order to test the level of significance of the variables. Consequently, with bootstrapping, hypotheses $\mathrm{H} 1 \mathrm{a}$ and $\mathrm{H} 1 \mathrm{e}$ are indicated to be significant with $\mathrm{t}$-value $>1.645$. As for the results of $\mathrm{H} 1 \mathrm{a}$, Tangibles $(\beta=2.06$ p<0.01, LL: 0.884, UL: 0.324) has a significant positive association with Behavioural Intention (BI), as was hypothesised. Likewise, Empathy (H1e) $(\beta=0.234$ p<0.01, LL: 0.0654, UL: 0.403) has a significant positive relation with Behavioural Intention (BI). As for H2, Customer Satisfaction $(\beta=0.586 \mathrm{p}<0.01$, LL: 0.435 , UL: 0.737$)$ demonstrated significant impact towards Behavioural Intentions (BI). While, hypotheses H1b, H1c and H1d failed to meet the threshold value of $>1.645$, marked not significant at the 0.05 significant level.

The larger the beta coefficient $(\beta)$, the stronger the influence of an exogenous latent construct on the latent construct. Table 5 illustrated that, when compared to the other $\beta$ scores in the framework, Empathy had the highest path coefficient of $\beta=0.234$ and $\beta=0.258$ towards Behavioural Intentions, showing a higher variance and high impact on the BI. The results are as tabulated in Table 5. 
Table 5 Structural Model and Hypothesis Testing (Direct Relationship)

\begin{tabular}{|c|c|c|c|c|c|}
\hline Hypothesis & Relationship & std beta & std error & t-value & Result \\
\hline H1a & Tangible->BI & 0.206 & 0.06 & $3.425^{* *}$ & Supported \\
\hline H1b & Reliability->BI & -0.003 & 0.099 & 0.04 & Not Supported \\
\hline H1c & Responsiveness->BI & -0.096 & 0.09 & 1.114 & Not Supported \\
\hline H1d & Assurance->BI & -0.03 & 0.088 & 0.287 & Not Supported \\
\hline H1e & Empathy->BI & 0.234 & 0.086 & $2.641^{*} *$ & Supported \\
\hline H2 & Satisfaction >BI & 0.586 & 0.077 & $7.664 * *$ & Supported \\
\hline
\end{tabular}

\section{Mediation Analysis}

The mediating effect of Customer Satisfaction (CS) between Perceived service quality and behavioural intentions. The results for indirect effect (Preacher and Hayes, 2004, 2008) demonstrated that $\mathrm{CS}$ (H3a) $(\beta=0.116, \mathrm{p}<0.01$, LL: 0.0278, UL: 0.204$)$ mediates the relationship between Tangibles and BI. Assurance $(\mathrm{H} 3 \mathrm{~d})(\beta=0.152, \mathrm{p}<0.05$, LL: 0.0148 , UL: $0.289)$ and Empathy $(\mathrm{H} 3 \mathrm{e})(\beta=0.264, \mathrm{p}<0.01, \mathrm{LL}: 0.146$, UL: 0.382$)$ respectively with BI were also shown to have been mediated by CS. The mediation analysis is reported in Table 6.

Table 6 Mediation Analysis

\begin{tabular}{|l|l|l|l|l|l|}
\hline Hypothesis & Relationship & Beta & Error & t-value & Result \\
\hline H3a & Tangibles > Satisfaction > BI & 0.116 & 0.045 & $2.658^{* *}$ & Mediated \\
\hline H3b & Reliability->Satisfaction-> BI & 0.016 & 0.062 & 0.344 & No Mediation \\
\hline H3c & Responsive->Satisfaction-> BI & 0.034 & 0.059 & 0.5 & No Mediation \\
\hline H3d & Assurance ->Satisfaction-> BI & 0.152 & 0.07 & $2.153^{*}$ & Mediated \\
\hline H3e & Empathy ->Satisfaction-> BI & 0.264 & 0.06 & $4.509^{* *}$ & Mediated \\
\hline
\end{tabular}

\section{Discussion}

In this study, most of the respondents had only visited a hospital once every few months. The outcome of this study was in parallel with a study done by Cheah, 2018 conducted in Sabah, Malaysia. Most of the participants frequented visited hospital for para-pharmaceuticals and non-prescription medications. It is interesting to find out that only Tangibles (PSQ) and Empathy (PSQ) are significant positive predictors of behavioural intentions, as hypothesised (H1a and H1e), whereas, Assurance (PSQ), Reliability (PSQ) and Responsiveness (PSQ) (H1b, $\mathrm{H} 1 \mathrm{c}$ and $\mathrm{H1d}$ ) have shown to be not supported as a positive predictor of Behavioural intentions. The result also showed that Empathy (PSQ) post more impact on customer satisfaction. The results have substantiated and contradicted prior research. This study consistent with the study findings held by Agyapong et al. (2017) which they investigate the mediating role of patients' satisfaction in the relationship between perceived service quality (PSQ) and behavioural intentions. In addition, the quality of the provision of healthcare in public and private healthcare facilities with regard to the level of treatment, attention and satisfaction received in healthcare facilities by patients (Agyapong et al., 2017). They also demonstrated that private healthcare facilities provide a higher level of treatment and attention than the public.

In the $\mathrm{H} 2$, customer satisfaction alone was empirically significantly anticipated on behavioural intentions in this research. Some research in the literature on consumer marketing has shown a similar relationship (Hartline and Jones, 1996; Selnes, 1993; Zeithaml et al., 1988). The findings of the research showed that satisfaction generally has a positive impact on the behaviour intent. The results for mediation showed that customer satisfaction functions as mediator of tangible, assurance, and empathy respectively with behavioural intentions 


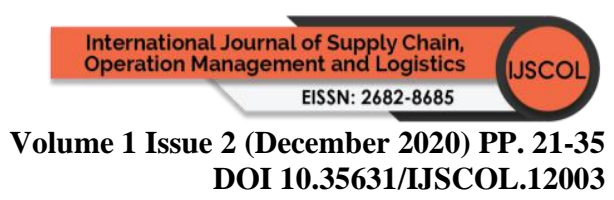

( $\mathrm{H} 3 \mathrm{a}, \mathrm{H} 3 \mathrm{~d}$ and $\mathrm{H} 3 \mathrm{e})$ but a mediating role for customer satisfaction between reliability and responsiveness respectively with behavioural intention $(\mathrm{H} 3 \mathrm{~b}$ and $\mathrm{H} 3 \mathrm{c})$ were not established. These results reflect Osman and Sentosa (2013), which endorsed customer satisfaction as a mediator between quality of service and customer loyalty in Malaysia's rural tourism sector. Based on the results, assurance has an indirect impact upon the behavioural intentions with customer satisfaction as mediation, despite not being endorsed in their direct connection.

\section{Conclusion}

This study comprehends trends and variables that affect the behavioural intention among visitors or patients of the hospitals in Sabah. Identifying and understanding which construct influences behavioural intentions could have a significant business implication, directly or indirectly (customer satisfaction as mediation). It is important to establish benchmarks for constructs being considered and to continuously monitor their performance through customer feedback. Those findings could be used in developing and implementing strategies among public and private hospitals in Sabah.

Customer satisfaction was linked to enhanced behavioural intentions and behavioural intentions are driven by their satisfaction with the experience in relation to the service quality aspect of tangibles, assurance and empathy in particular. Based on this analysis, since the indirect impact of assurance and empathy are seen as a stronger driving force for behavioural intentions, marketing strategies and efforts in promoting their service quality (Agyapong, 2017) should seek to establish assurance and empathy, with a focus on improving customer satisfaction that would contribute to improving behavioural intentions.

\section{Acknowledgement}

This study funded under SDK0052/2018 Human Resource Management of Hospital UMS (HUMS). Thank you to Centre of Research and Innovation, UMS.

\section{References}

Aagja, J. A. and Garg, R. (2010). Measuring perceived service quality for public hospitals (PubHosQual) in the Indian context. International Journal of Pharmaceutical and Healthcare Marketing, 4(1), 60-83.

Agyapong, A., Afi, J. D. and Kwateng, K. O., (2017). Examining the effect of perceived service quality of health care delivery in Ghana on behavioural intentions of patients: The mediating role of customer satisfaction. International Journal of Healthcare Management, 11(4), 276-288. https://doi.org/10.1080/20479700.2017.1326703

Ali, Faizan and Amin, Muslim. (2013). The Influence of Physical Environment on Emotions, Customer Satisfaction and Behavioural Intentions in Chinese Resort Hotel Industry.

Alumran, A., Almutawa, H., Alzain, Z., Althumairi, A. and Khalid, N. (2020). Comparing public and private hospitals' service quality. Journal of Public Health: From Theory to Practice. DOI: 10.1007/s10389-019-01188-9

Anderson, E. W. (1998). Customer satisfaction and word of mouth. Journal of Service Research, 1(1), 5-17

Anthanassopoulos, A., Gounaris, S. and Sathakopoulos, V. (2001). Behavioural responses to customer satisfaction: an empirical study. European Journal of Marketing, 35(5/6), 687707.

Antonides, G. and Van Raaij, F. W. (1998). Consumer Behaviour: A European Perspective, Wiley, London. 


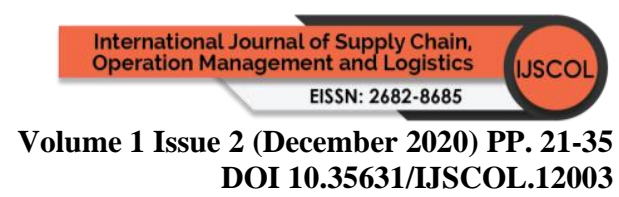

Argawal, J. and Malhotra, N.K. (2005). An integrated model of attitude and affect: theoretical foundation and an empirical investigation. Journal of Business Research, 58(4), 48393.

Assael, H. (2004). Consumer behaviour: A strategic approach, Boston: Houghton Mifflin Company. 216.

Babakus, E. and Boller, G. W. (1991). An empirical assessment of the SERVQUAL scale. Journal of Business Research, 24(3), 253-268.

Bei, L. T. and Chiao, Y. C. (2001). An integrated model for the effects of perceived product, perceived service quality, and perceived price fairness on consumer satisfaction and loyalty. Journal of Consumer Satisfaction, Dissatisfaction and Complaining Behaviour, $14,125-40$.

Borneo Post Online. (December 12, 2010) Public versus private on medical care. http://www.theborneopost.com/2010/12/12/public-versus-private-on-medical-care/

Boulding, W., Kalra, A., Staelin, R. and Zeithaml, V. A (1993). A Dynamic Process Model of Service Quality: From Expectations to Behavioral Intentions. Journal of marketing research. 30. 7-27.

Brady and Christopher, J. R. (2001). Searching for a Consensus on the Antecedent Role of Service Quality and Satisfaction: An Exploratory Cross-National Study. Journal of Business Research, 51(1), 53-60.

Caro, L. M., and Garcia, J. A. M. (2007). Consumer satisfaction with a periodic reoccurring sport event and the moderating effect of motivations. Sport Marketing Quarterly, 16(2), $70-81$.

Caruana, A. (2002). Service loyalty: the effects of service quality and the mediating role of customer satisfaction. European Journal of Marketing, 36, 811-828.

Cronin and Steven A. T. (1994). SERVPERF versus SERVQUAL: Reconciling PerformanceBased and Perceptions-Minus - Expectations Measurement of Service Quality.Journal of Marketing, 58, 125-131.

Cronin, Jr. J., Brady, M and Hult, T. (2000). Assessing the effects of quality, value, and customer satisfaction on consumer behavioral intentions in service environments. Journal of Retailing, 76. 193-218.

Cronin. Jr, J., and Taylor, S. (1992). Measuring Service Quality - A Reexamination And Extension. The Journal of Marketing, 56, 55-68.

Dabholkar, P. A., Shepherd, C. D. and Thorpe, D. I. (2000). A comprehensive framework for service quality: an investigation of critical conceptual and measurement issues through a longitudinal study.Journal of Retailing, 73(2), 139-73

Darry S. Penceliah, Dion T. Noel and Nafisa Adat (2015). Customer satisfaction within pharmacies in a supermarket: A South African perspective. Problems and Perspectives in Management, 13(2-si), 452-459

Duku, S. K. O., Nketiah-Amponsah, E, Janssens, W., and Pradhan, M. (2018). Perceptions of healthcare quality in Ghana: Does health insurance status matter? PLoS ONE, 13(1), e0190911. https:// doi.org/10.1371/journal.pone.0190911

Economic Transformation Programme; Healthcare. http://etp.pemandu.gov.my/Healthcare@-Healthcare.aspx.

Finkelstein, B. S., Harper, D. L. and Rosenthal, G. E. (1999). Patient assessments of hospital maternity care: a useful tool for consumers? Health Services Research, 34(2), 623-640.

Gaur, S. S., Xu, Y., Quazi, A. and Nandi, S. (2011). Relational impact of service providers' interaction behavior in healthcare", Managing Service Quality, 21(1), 67-87.

Goldstein, S. M. and Schweikhart, S. B. (2002). Empirical support for the Baldrige Award framework in US hospitals. Healthcare Management Review, 27(1), 62-75. 


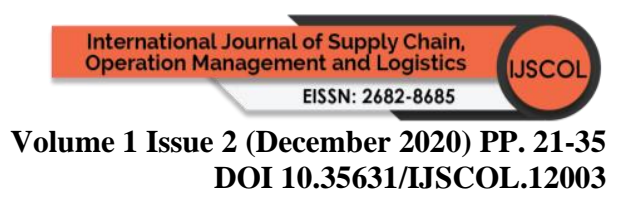

Gooding, S. K. S. (1995). Quality, sacrifice, and value in hospital choice”, Journal of Healthcare Marketing, 15(4), 24-31.

Gotlieb, J. B., Dhruv, G. and Stephen, W. B. (1994). Consumer Satisfaction and Perceived Quality: Complementary or Divergent Constructs? Journal of Applied Psychology, 79 (6), 875-885

Grönroos, C. (1984). A service quality model and its marketing implications", European Journal of Marketing, 18(4), 36-44.

Hair, J. F., Hult, G. T. M., Ringle, C. M. and Sarstedt, M. (2014). A Primer on Partial Least Squares Structural Equation Modeling (PLS-SEM), SAGE, Los Angeles, CA.

Hair, J. F., Hult, G. T. M., Ringle, C.M. and Sarstedt, M. (2017). A Primer on Partial Least Squares Structural Equation Modeling (PLS-SEM), 2nd ed., Sage, Thousand Oaks, CA.

Hartline, M. D. and Jones, K. C. (1996). Employee performance cues in a hotel service environment: influence on perceived service quality, value and word-of-mouth intentions", Journal of Business Research, 35(3), 207-215.

Hassali, M. A., Mak, V. S. and See, O. G. (2014). Pharmacy practice in Malaysia. J Pharm Pract Res, 44, 125-128.

Kessler, D. P. and Mylod, D. (2011). Does patient satisfaction affect patient loyalty? International Journal of Healthcare Quality Assurance, 24(4), 266-273.

Lazarus, R. S. (1982), "Thoughts on the relation between emotion and cognition", American Psychology, 37(9), 1019-24.

Lazarus, R. S. (1991), Emotion and Adaptation, Oxford University Press, New York, NY.

Lewis, B. R. (1991). Service quality: an international comparison of bank customers' expectations and perceptions.Journal of Marketing Management, 7(1), 47-62.

Nitzl, C., Roldan, J. L. and Carrion, G. C. (2016). Mediation analysis in partial least squares path modelling: helping researchers discuss more sophisticated models. Industrial Management and Data Systems, 116(9), 1849-1864.

Oliver, R. (1997), Satisfaction: A Behavioural Perspective on the Consumer, McGraw Hill, New York, NY.

Oliver, R. L. (1980). A cognitive model of the antecedents and consequences of satisfaction decisions. Journal of Marketing Research, 17, 460-469.

Oliver, R. L. (1993). A conceptual model of service quality and service satisfaction: compatible goals, different concepts. Teresa, A.S., David, E.B. and Stephen, W.B. (Eds), Advances in Marketing and Management, JAI Press, Greenwich, CT, 65-85.

Osman, Z., and Sentosa, I. (2013). Service Quality and Customer Loyalty in Malaysian Rural Tourism: A Mediating Effect of Trust. International Journal of Marketing Practices, 1, 31-42.

Parasuraman, A., Zeithaml, V. A. and Berry, L. L. (1988). SERVQUAL: a multiple-item scale for measuring consumer perceptions of service quality. Journal of Retailing, 64(1), 12 40.

Riadh, L. (2009). Service quality, emotional satisfaction, and behavioural intentions: A study in the hotel industry. Managing Service Quality: An International Journal, 19(3), 308331.

Richter, N. F., Sinkovics, R. R., Ringle, C. M. and Schlägel, C. (2016).A critical look at the use of SEM in international business research", International Marketing Review, 33(3), 376-404.

Rui, B., Abel, C., Masayuki, Y., António, R., João, M. (2013). The role of service quality and ticket pricing on satisfaction and behavioural intention within professional football. International Journal of Sports Marketing and Sponsorship, 14(4), 42-66. 
Rust, R. T. and Oliver, R. L. (1994). Service quality: insights and managerial implications from the frontier, in Rust, R. T. and Oliver, R. L. (Eds), Service Quality: New Directions in Theory and Practice, Sage, New York, NY, 1-19.

Ryu, G. and Han, J. K. (2009). Word-of-mouth transmission in settings with multiple opinions: the impact of other opinions on WOM likelihood and valence. Journal of Consumer Psychology, 19(3), 403-15.

Sang, S., Lee, J. D. and Lee, J. (2010). E-government adoption in Cambodia. a partial least squares approach. Transforming Government: People, Process and Policy, 4(2), 138157.

Sarker, Md and Uddin, B. (2017). Influence of Service Quality on Customer Satisfaction in Retail Banking: A Study on Some Private Commercial Banks in Bangladesh.

Sayyed M. A., Javad, Pool, A. J., Reza, S., Hassan, A. (2015). Factors influencing sport tourists' revisit intentions: The role and effect of destination image, perceived quality, perceived value and satisfaction. Asia Pacific Journal of Marketing and Logistics, 27(2), 191-207.

Schiffman, L. G., and Kanuk, L. L. (2004). Consumer behaviour, 8th ed. Upper Saddle River, New Jersey: Pearson Prentice Hall, 256

Selnes, F. (1993). An examination of the effect of product performance on brand reputation, satisfaction and loyalty. European Journal of Marketing, 27(9), 19-35.

Shan, L., Li, Y., Ding, D., Wu, Q., Liu, C., and Jiao, M. (2016). Patient Satisfaction with Hospital Inpatient Care: Effects of Trust, Medical Insurance and Perceived Quality of Care. PLoS ONE, 11(10): e0164366. doi: 10.1371/journal.pone.0164366

Sik, S. I., Gede, M. Y. B., Tri Rakhmawati, Nidya, J. A., Tri Widianti, Medi, Y. (2014). The empirical study on patient loyalty: The role of trust, perceived value, and satisfaction (a case study from Bekasi, Indonesia), Clinical Governance: An International Journal, 19(3), 269-283.

Solomon, M. R. (2002). Consumer behaviour. UpperSaddle River, New Jersey: Prentice Hall, 200

Zeithaml, V. A., Berry, L. L. and Parasuraman, A. (1988). Communication and control processes in the delivery of service quality. Journal of Marketing, 52, 35-48.

Zeithaml, V. A., Berry, L. L. and Parasuraman, A. (1996). The behavioral consequences of service quality. Journal of Marketing, 60(2), 31-46. 